\title{
Purification, characterization and retting of Crotolaria juncea fibres by an alkaline pectin lyase from Fusarium oxysporum MTCC 1755
}

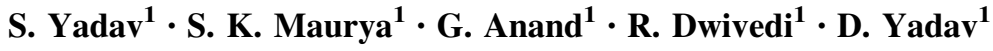

Received: 22 November 2016/Accepted: 30 January 2017/Published online: 8 June 2017

(C) Springer-Verlag Berlin Heidelberg 2017

\begin{abstract}
Using solid-state fermentation, production of an industrially important pectin lyase from a fungal strain Fusarium oxysporum MTCC 1755 was attempted, which was further subjected to purification and characterization. The enzyme was purified by three steps, namely ammonium sulfate fractionation, cation-exchange chromatography on CM cellulose followed by gel filtration chromatography using Sephadex G-100 column. A 16-fold purification with $31.2 \%$ yield and $3.2 \mathrm{U} / \mathrm{mg}$ specific activity was achieved. The optimum $\mathrm{pH}$ of the purified enzyme was 9.0 and stability ranged from $\mathrm{pH}$ 5.0-7.0 for $24 \mathrm{~h}$. Optimum temperature of purified enzyme was found to be $40{ }^{\circ} \mathrm{C}$ while temperature stability ranged from 10 to $50{ }^{\circ} \mathrm{C}$ for $30 \mathrm{~min}$. The $K_{\mathrm{m}}$ and $k_{\text {cat }}$ of the enzyme was $1.75 \mathrm{mg} / \mathrm{ml}$ and $83.3 \mathrm{~s}^{-1}$, respectively. The purified enzyme was found to be highly stimulated by $\mathrm{Ca}^{2+}$ ions while sugars like mannitol and sorbitol, and salts like $\mathrm{NaCl}$ and $\mathrm{CaCl}_{2}$ enhanced the thermostability. The purified pectin lyase was found suitable for retting of Crotolaria juncea fiber.
\end{abstract}

Keywords Pectin lyase - Fusarium oxysporum MTCC $1755 \cdot$ Retting $\cdot$ Purification

S. Yadav

sangeeta_rahul@rediffmail.com

1 Department of Biotechnology, DDU Gorakhpur University, Gorakhpur 273009, India

\section{Introduction}

Pectic substances are high molecular weight, negatively charged, acidic, complex glycosidic macromolecules (polysaccharides) that are present in the plant kingdom. They are present as the major components of middle lamella between the cells in the form of calcium pectate and magnesium pectate (Bonnin et al. 2014). Pectic polysaccharides exist in the cell wall as either "smooth region" of linear copolymer $\alpha$ (1-4)-linked GalUA (galacturonic acid) or "hairy region" that have attached $\alpha$ (1-2)-linked rhamnosyl residues that may be substituted with Ara (arabinan)- and Gal (galactan)-rich side chains (Caffall and Mohnen 2009). A group of enzymes popularly known as pectinases are associated with degradation of pectin and includes exo- and endo-polygalacturonases (PGs, E.C 3.2.115), pectin methyl esterases (PME.E.C 3.2.1.11), pectate lyases (PL,E.C 4.2.2.9) and pectin lyases (PNL 4.2.2.10). These enzymes are widely distributed in higher plants and microorganisms (Whitaker 1990) and are of prime importance for plants as they help in cell wall extension and softening of some plant tissues during maturation and storage (Aguilar and Huirton 1990; Sakai 1992). They also aid in maintaining ecological balance by causing decomposition and recycling of waste plant materials. Pectin lyase is unique among all pectinases based on the $\beta$-elimination reaction mechanism and since it does not produce methanol, it is preferred in fruit juice industries (Yadav et al. 2009).

Several potential industrial applications of pectinases such as clarification of fruit juices, retting of natural fibers, treatment of pectic waste water, coffee and tea leaf fermentation, oil extraction, virus purifications and developing functional foods have been reported (Kohli and Gupta 2015; Sharma et al. 2013; Kashyap et al. 2001). 
Solid-state fermentation (SSF) and submerged fermentation $(\mathrm{SmF})$ are the two popular conventional methods for the production of enzymes from microbial sources. SSF has advantage over $\mathrm{SmF}$ as it aims to achieve the highest substrate concentration for fermentation by bringing a cultivated fungus or bacterium into close contact with the insoluble substrate and is also economically more feasible. It involves use of abundant and cheap substrates, which are mostly the waste products, such as wheat bran, sugarcane bagasse and orange peel (Meenakshisundaram 2012; Tivkaa et al. 2013; Kashyap et al. 2003; Martin et al. 2004).

In general, enzyme production by microbes depends on several factors such as composition of growth medium, cultivation conditions like $\mathrm{pH}$, temperature, aeration, agitation, and incubation time. Filamentous fungi are the most preferred microorganism in the enzyme industry due to the fact that as much as $90 \%$ of the enzymes produced by these fungi are extracellular in nature (Jun et al. 2011). Several fungal strains have been reported for the production of pectin lyases as reviewed (Yadav et al. 2009); however, strains representing Fusarium genera are few (Yadav et al. 2014). The acidic and alkaline pectin lyases are generally used for fruit juice clarification and retting of fibers, respectively. In the present manuscript, purification and enzymatic characterization of an alkaline pectin lyase from Fusarium oxysporum MTCC 1755 with its possible application in retting have been discussed.

\section{Materials and methods}

\section{Chemicals}

All the chemicals used were either procured from SigmaAldrich (USA) or HIMEDIA (Mumbai, India) and were of high analytical grade. Pectin from citrus fruit (Sigma) was used as the substrate. The fungus Fusarium oxysporum MTCC 1755 was procured from MTCC Centre and Gene Bank, Institute of Microbial Technology, Chandigarh, India.

\section{Maintenance of Fusarium oxysporum MTCC 1755 and PNL production}

The fungal strain was cultured on Potato Sucrose Agar (PSA) slants and incubated at $25^{\circ} \mathrm{C}$ for 7 days. The heavily sporulated slants were stored at $4{ }^{\circ} \mathrm{C}$ and subculturing was done after every 3 months. The enzyme was produced by solid-state fermentation and the production medium consisted of $5 \mathrm{~g}$ of wheat bran and $7 \mathrm{ml}$ of salt solution. The salt solution consisted of $4 \mathrm{gL}^{-1}$ each of $\mathrm{K}_{2} \mathrm{HPO}_{4}, \mathrm{KH}_{2} \mathrm{PO}_{4}$, and $\left(\mathrm{NH}_{4}\right)_{2} \mathrm{SO}_{4}$. The spores were harvested by adding $1 \mathrm{ml}$ of sterile distilled water. About
$5 \times 10^{5}$ spores were required for maximum production of the enzyme. A total of $10 \times 250-\mathrm{ml}$ Erlenmeyer flasks containing solid medium were inoculated and were kept at $25{ }^{\circ} \mathrm{C}$ in a biological oxygen demand incubator (BOD). Maximum production occurred on the 7 th day of incubation.

\section{Enzyme extraction and assay}

For extraction of crude enzyme, $15 \mathrm{ml}$ of chilled distilled water was added to each flask and the resulting mixture was homogenized by a glass rod. The homogenate was extracted through four layers of cheese cloth and the filtrate was centrifuged at $10,000 \mathrm{rpm}$ for $20 \mathrm{~min}$. The clear supernatant obtained was used as crude enzyme for purification. Enzyme activity of PNL was assayed by the method reported in the literature (Albersheim 1966). Enzyme solution $(0.2 \mathrm{ml})$ was added to a reaction mixture containing $0.8 \mathrm{ml}$ of citrus pectin $(1 \%)$ and $2.0 \mathrm{ml}$ of the $100 \mathrm{mM}$ glycine-NaOH buffer (pH 9.0). It was incubated at $37^{\circ} \mathrm{C}$ in a water bath and the optical density was measured. Enzyme activity was measured at zero time and after $20 \mathrm{~min}$ at $235 \mathrm{~nm}$ and the steady-state velocity was calculated by absorbance change per minute. Enzyme activity was defined in terms of $\mu$ mole of unsaturated product released per min, based on molar extinction coefficient value of $5500 \mathrm{M}^{-1} \mathrm{~cm}^{-1}$. Protein was determined by the standard Lowry-Folin method (Lowry et al. 1951) using bovine serum albumin as standard. All the experiments were performed in triplicates and were found to have standard deviation of less than $5 \%$.

\section{Enzyme purification}

Finely powdered ammonium sulfate was added to $100 \mathrm{ml}$ of crude enzyme preparation with gradual stirring up to $30 \%$ saturation at $4{ }^{\circ} \mathrm{C}$ and the resulting solution was kept in the fridge overnight. Next morning it was centrifuged at $10,000 \mathrm{rpm}$ for $15 \mathrm{~min}$. The pellet was discarded and the supernatant was saturated up to $90 \%$ with ammonium sulfate and allowed to stand overnight. It was again centrifuged at 10,000 rpm for $20 \mathrm{~min}$. The pellet was dissolved in $10 \mathrm{mM}$ citrate buffer ( $\mathrm{pH}$ 5.0). This fraction was dialysed against 1000 times excess of $10 \mathrm{mM}$ citrate buffer (pH 5.0) with sequential three changes to remove the salt completely.

The dialysate was centrifuged at $5000 \mathrm{rpm}$ for $5 \mathrm{~min}$ to get a clear transparent concentrated enzyme. This was allowed to bind to the CM cellulose resin $(3.0 \mathrm{~g})$ in a beaker $(100 \mathrm{ml})$ by batch procedure. The resin was preequilibrated with $20 \mathrm{mM}$ citrate phosphate buffer ( $\mathrm{pH} 5.0$ ), as this was the $\mathrm{pH}$ at which the enzyme was found to bind maximally. The resin was washed with $15 \mathrm{ml}$ of buffer to 
remove other undesired protein. The resin was allowed to settle down at $4{ }^{\circ} \mathrm{C}$ and again washed with $15 \mathrm{ml}$ of $20 \mathrm{mM}$ citrate buffer (pH 5.0) with $1.5 \mathrm{M} \mathrm{NaCl}$ to elute out the bound protein. This eluted product was tested for PNL activity, protein concentration and also for homogeneity.

The eluent obtained was concentrated by Amicon ultrafiltration unit and was used for next step of purification. The concentrated enzyme was dialysed against $10 \mathrm{mM}$ citrate phosphate buffer $(\mathrm{pH} 6.8)$ and was loaded on Sephadex G-100 column $(22 \mathrm{~cm} \times 1.1 \mathrm{~cm})$ equilibrated with $50 \mathrm{mM}$ citrate phosphate buffer ( $\mathrm{pH}$ 6.8). The flow rate was maintained at $10 \mathrm{ml} \mathrm{hr}^{-1}$ and fractions of $2 \mathrm{ml}$ each were collected, assayed, pooled and stored in deep fridge at $-20{ }^{\circ} \mathrm{C}$.

\section{Biochemical characterization of purified PNL}

\section{Determination of homogeneity and molecular mass of purified $P N L$}

The enzyme purity and relative molecular weight were estimated by the SDS-PAGE method of Laemmli (Laemmli 1970). A standard protein marker comprising protein bands in the range of $10-250 \mathrm{kDa}$, with a distinguished color reference bands, namely orange for 71 and $29 \mathrm{kDa}$ and green for $10 \mathrm{kDa}$ band was used. Silver staining was done for locating the protein bands.

\section{Optimum $p H$ and $p H$ stability of purified $P N L$}

Optimum $\mathrm{pH}$ was determined by measuring the steadystate velocity in the buffered reaction solution in the $\mathrm{pH}$ range 1.0-12.0 and plotting steady-state velocity against the $\mathrm{pH}$ of the reaction solution. The different buffers used were: $\mathrm{HCl}-\mathrm{KCl}$ (1.0-2.0), citrate phosphate buffer (3.0-5.0), sodium phosphate (6.0-8.0), glycine- $\mathrm{NaOH}$ (9.0-10.0) and sodium phosphate- $\mathrm{NaOH}(11.0-12.0)$, all at $100 \mathrm{mM}$ concentration. The $\mathrm{pH}$ stability of the purified pectin lyase was studied by exposing the enzyme at a particular $\mathrm{pH}$ for $24 \mathrm{~h}$ at $4{ }^{\circ} \mathrm{C}$ and consequently plotting the percent residual activity against the $\mathrm{pH}$ at which the enzyme has been exposed.

\section{Optimum temperature and thermostability of the purified $P N L$}

The temperature optimum was determined by measuring steady-state velocity of the enzyme-catalyzed reaction at different temperatures and plotting steady-state velocity against temperature. The thermal stability of the enzyme was tested by two separate experiments: in one experiment enzyme aliquots were allowed to remain at different temperature for half an hour and their activities were assayed using the standard assay method. The percent residual activity after half an hour was plotted against temperature. In the second experiment, an enzyme sample was kept at different temperatures (viz., 40, 50 and $60{ }^{\circ} \mathrm{C}$ ), aliquots were withdrawn after $15,30,60$ and $120 \mathrm{~min}$ and were assayed using standard assay method.

\section{Effects of substrate concentration}

The $K_{\mathrm{m}}$ and $k_{\text {cat }}$ values of the purified enzyme were determined by measuring steady-state velocities of the enzyme-catalyzed reaction at different concentrations of citrus pectin and drawing Michaelis-Menten curve and double reciprocal Lineweaver-Burk plot.

\section{Effect of divalent cations and protein inhibitors}

The enzyme activity was determined in the presence of various metal ions, namely $\mathrm{Ag}^{+}, \mathrm{Ca}^{2+}, \mathrm{Co}^{2+}, \mathrm{Cu}^{2+}, \mathrm{Hg}^{2+}$, $\mathrm{K}^{+}, \mathrm{Mg}^{2+}, \mathrm{Zn}^{2+}, \mathrm{Na}^{+}, \mathrm{Mn}^{2+}$, and protein inhibitors such as EDTA, sodium azide, potassium permanganate and potassium ferrocyanide at $1 \mathrm{mM}$ concentration.

\section{Effect of salts and sugars on thermostability of the purified} $P N L$

Salts and sugars like magnesium chloride, calcium chloride (5-10 mM); sodium chloride, glycine $(0.5-1.0 \mathrm{M})$; glycerol, mannitol and sorbitol (10-20\%) were incorporated in the reaction mixture and incubated at $50{ }^{\circ} \mathrm{C}$ for one hour to study the thermal stability of the purified enzyme.

\section{Retting of natural fiber}

The retting of Crotalaria juncea (Sunnhemp) fiber was studied (Zhang et al. 2005). The fiber sticks of $5 \mathrm{~cm}$ were incubated in $10 \mathrm{ml}$ of $100 \mathrm{mM}$ glycine- $\mathrm{NaOH}$ buffer $(\mathrm{pH}$ 9.0) in two sets, one containing 0.01 M EDTA and other lacking EDTA. An aliquot (100 $\mu \mathrm{l})$ of enzyme was added in both the sets and the reaction mixtures were incubated for $24 \mathrm{~h}$ at $37{ }^{\circ} \mathrm{C}$ in water bath. Control tubes with inactivated enzyme were simultaneously maintained. After $24 \mathrm{~h}$, the sticks were shaken vigorously with $10 \mathrm{ml}$ of hot water for one minute and the hot water was poured off and the resulting sticks were photographed.

\section{Results}

\section{Enzyme purification}

The different steps of purification of pectin lyase produced by Fusarium oxysporum MTCC 1755 is shown in Table 1. 
Table 1 Purification chart of PNL secreted by Fusarium oxysporum MTCC 1755

\begin{tabular}{llllll}
\hline Fraction & Total activity (IU) & Total protein (mg) & Specific activity & Fold purification & $\%$ yield \\
\hline Crude & 54 & 26 & 0.2 & - & - \\
Ammonium sulfate (30-90\%) & 27.5 & 21.25 & 1.29 & 1.8 & 6.45 \\
CM cellulose & 11.2 & 6.2 & 3.2 & 9.0 & 20.7 \\
Sephadex G-100 & 16.8 & 5.2 & & 31.2 \\
\hline
\end{tabular}

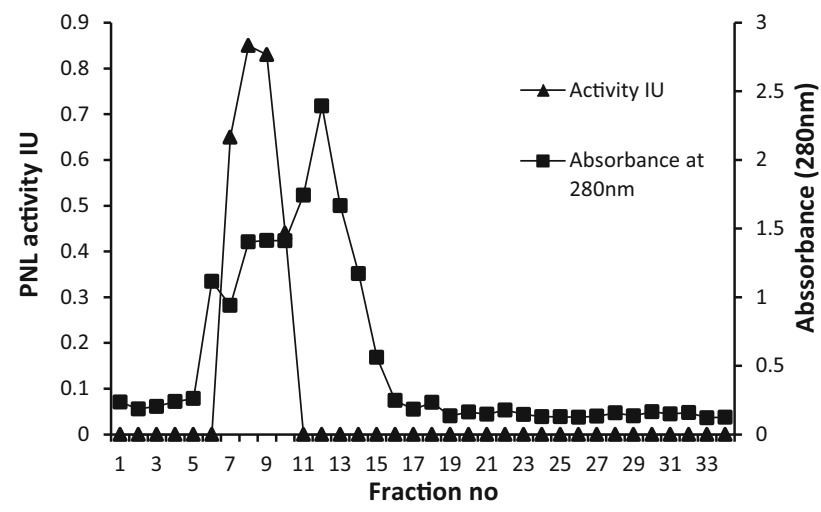

Fig. 1 Gel filtration purification profile of PNL from Fusarium oxysporum MTCC 1755

The crude enzyme had specific activity of $0.2 \mathrm{U} / \mathrm{mg}$. $50 \%$ of the enzyme gets precipitated between 30 and $90 \%$ of ammonium sulfate saturation and the specific activity increased to $1.2 \mathrm{U} / \mathrm{mg}$. The specific activity increased to $1.8 \mathrm{U} / \mathrm{mg}$ and the recovery was $20.7 \%$ after ion exchange in batch technique. In the final purification step by gel filtration chromatography by Sephadex G-100 column, most of the activity was present in a single protein peak, which was well separated from other protein peaks, indicating that the enzyme preparation was pure as shown in Fig. 1.

The specific activity was enhanced to $3.2 \mathrm{U} / \mathrm{mg}$ and 16-fold purification fold was achieved. The homogeneity of the purified enzyme was confirmed by performing $10 \%$ SDS-PAGE, where a single prominent band was obtained (Fig. 2). The molecular weight of the purified enzyme was determined by plotting the log of molecular weights of the markers versus their relative mobility (Werber and Osborn 1969) which was determined to be approximately $31 \pm 01 \mathrm{kDa}$.

\section{Biochemical properties of purified pectin lyase of Fusarium oxysporum MTCC 1755}

The variation in activity of purified pectin lyase with $\mathrm{pH}$ of the reaction medium is shown in Fig. 3.

The $\mathrm{pH}$ optimum was found to be 9.0 and the enzyme shows $98 \%$ of its activity in $\mathrm{pH}$ range $9.0-10.0$. The results

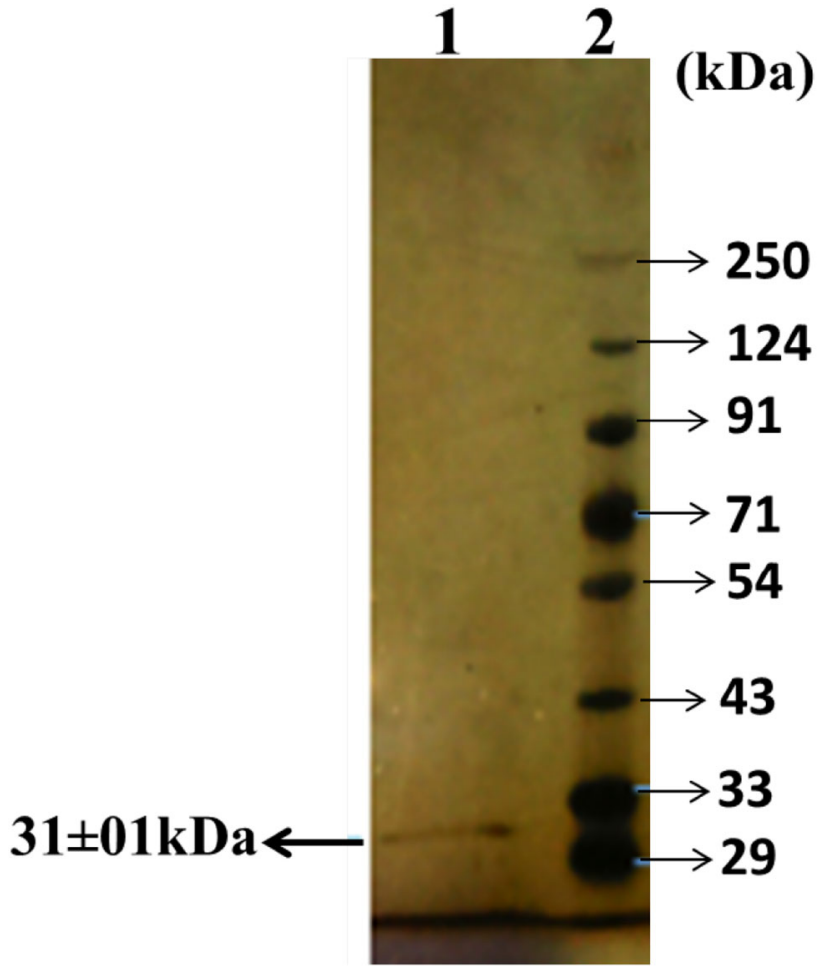

Fig. 2 SDS-PAGE of PNL purified from $F$. oxysporum 1755. Lane 1 purified PNL; Lane 2 protein marker

of the studies on $\mathrm{pH}$ stability of purified pectin lyase are also shown in Fig. 3. The graph shows that the enzyme retains most of its activity if left for $24 \mathrm{~h}$ in a buffer of $\mathrm{pH}$ range 5.0-7.0.

The temperature optimum of the enzyme is $40{ }^{\circ} \mathrm{C}$ (Fig. 4a). The percentage residual activity versus temperature at which enzyme has been kept for half an hour shows that the enzyme retains its full activity up to $50{ }^{\circ} \mathrm{C}$ and thereafter activity is decreased, with increase in temperature (Fig. 4b). However, $32 \%$ of residual activity is lost after incubating the purified PNL at $60{ }^{\circ} \mathrm{C}$ for half an hour.

The $K_{\mathrm{m}}$ and $k_{\text {cat }}$ calculated from Lineweaver-Burk plots (Fig. 5) were $1.75 \mathrm{mg} / \mathrm{mL}$ and $83.3 \mathrm{~s}^{-1}$, respectively.

The results of the effects of metal ions at $1 \mathrm{mM}$ concentration of $\mathrm{Ag}^{+}, \mathrm{Ca}^{2+}, \mathrm{Co}^{2+}, \mathrm{Cu}^{2+}, \mathrm{Hg}^{2+}, \mathrm{K}^{+}, \mathrm{Mg}^{2+}$, $\mathrm{Zn}^{2+}, \mathrm{Na}^{+}, \mathrm{Mn}^{2+}$ and protein inhibitors such as EDTA, sodium azide, potassium permanganate and potassium 


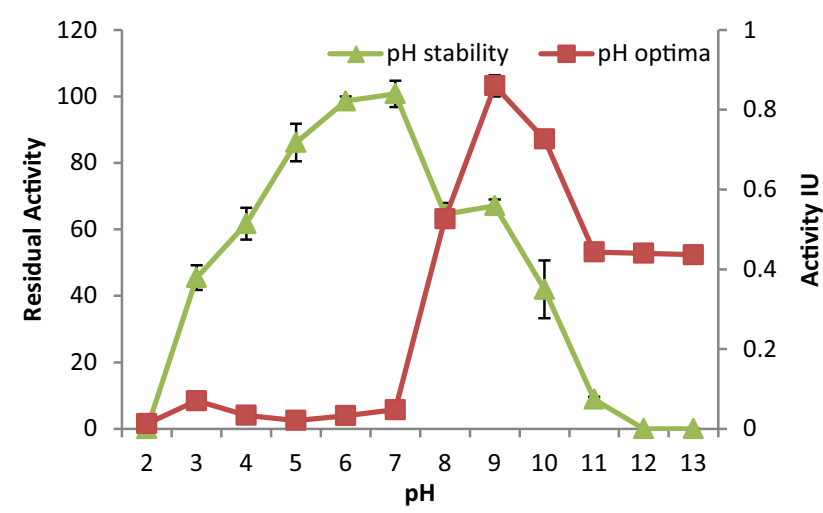

Fig. 3 Optimum $\mathrm{pH}$ black filled square and $\mathrm{pH}$ stability black filled triangle of purified PNL from $F$. oxysporum MTCC 1755. The vertical bars indicate standard deviation (SD) of the mean calculated for three readings

ferrocyanide on the activity of pectin lyase are summarized in Table 2. It was observed that $\mathrm{Ca}^{2+}$ significantly increased the PNL activity while $\mathrm{K}^{+}, \mathrm{Na}^{+}, \mathrm{Zn}^{2+}, \mathrm{Ag}^{+}$, $\mathrm{Hg}^{2+}, \mathrm{Co}^{2+}$ and $\left(\mathrm{NH}_{4}\right)_{2} \mathrm{SO}_{4}$ were also found to be stimulating the PNL activity whereas, potassium ferrocyanide and potassium permanganate inhibited the activity of the purified pectin lyase completely.

\section{Effect of salts and sugars on thermostability of the purified PNL}

As shown in Fig. $4 \mathrm{~b}$, the purified enzyme was thermally stable for half an hour up to $50{ }^{\circ} \mathrm{C}$ and activity decreased sharply thereafter. Effects of a few salts and sugars were tested when exposed for an hour at $50{ }^{\circ} \mathrm{C}$. It was observed

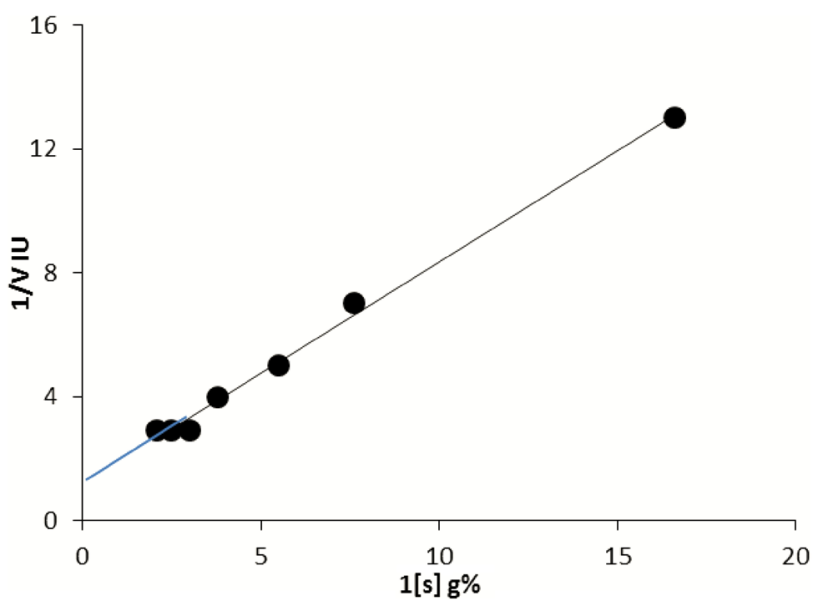

Fig. 5 Double reciprocal Lineweaver-Burk plot of purified PNL of F. oxysporum MTCC 1755

that $\mathrm{CaCl}_{2}$ increased the PNL activity at $10 \mathrm{mM}$ concentration while sugars like mannitol and sorbitol maintain the stability. $\mathrm{MgCl}_{2}$ and glycine were found to decrease the activity (Table 3 ).

\section{Retting of natural fiber Crotolaria juncea in the presence of purified pectin lyase}

The results of studies of retting experiments on mature Crotolaria juncea sticks by the purified enzyme in $24 \mathrm{~h}$ are shown in Fig. 6. It is quite interesting to note that the retting of Crotolaria juncea sticks by the purified enzyme is accomplished in the absence of EDTA, which is generally required for retting.

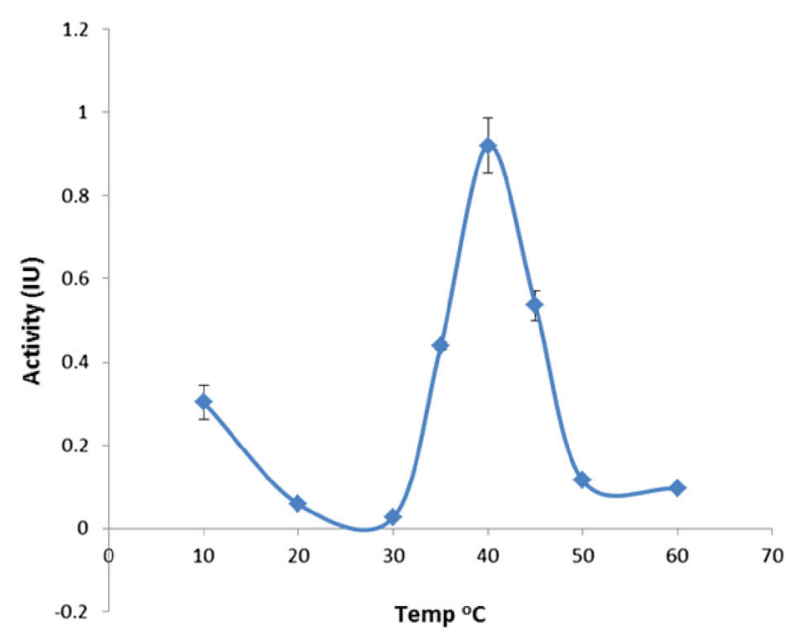

$\mathbf{A}$

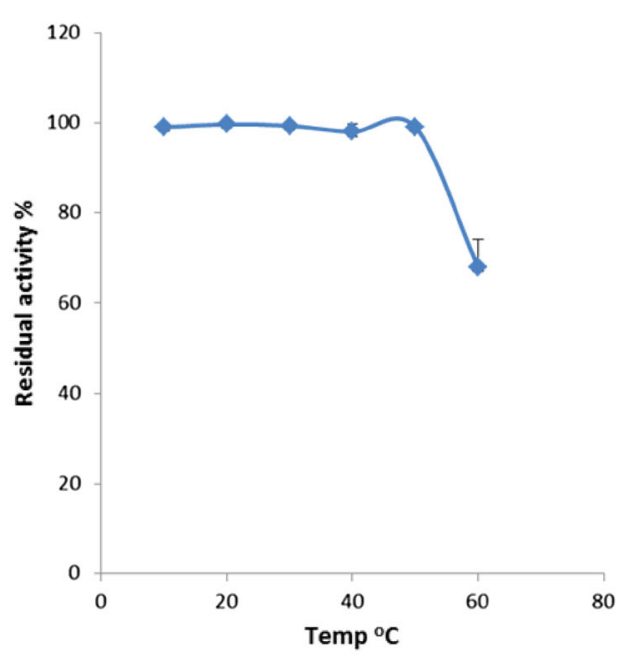

B

Fig. 4 The optimum temperature (a) and thermostability (b) of purified PNL of F. oxysporum MTCC 1755. The vertical bars indicate standard deviation $(\mathrm{SD})$ of the mean calculated for three readings

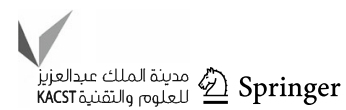


Table 2 Effect of metal ions and protein inhibitors on activity of purified PNL

\begin{tabular}{ll}
\hline Metal ions/protein inhibitor & Relative activity $(\%)$ \\
\hline Metal ions $(1.0 \mathrm{mM})$ & 100 \\
$\mathrm{Control}$ & 2886 \\
$\mathrm{CaCl}_{2}$ & 200 \\
$\mathrm{KCl}$ & 100 \\
$\mathrm{CuSO}_{4}$ & 181 \\
$\mathrm{NaCl}_{\mathrm{ZnSO}}$ & 131 \\
$\mathrm{AgNO}_{3}$ & 416 \\
$\mathrm{CoCl}_{2}$ & 336 \\
$\mathrm{HgCl}_{2}$ & 360 \\
$\mathrm{Citric}$ acid & 78 \\
$\left(\mathrm{NH}_{4}\right)_{2} \mathrm{SO}_{4}$ & 203 \\
Protein inhibitors $(1.0 \mathrm{mM})$ & \\
EDTA & 10.2 \\
Sodium arsenate & 91.7 \\
Sodium azide & 125 \\
Potassium permanganate & 0.0 \\
Potassium ferrocyanide & 0.0 \\
\hline
\end{tabular}

Table 3 Effects of different concentration of salts and sugars on thermostability of purified PNL of Fusarium oxysporum 1755

\begin{tabular}{lllc}
\hline Sl no. & Salt/sugar & Concentration & $\begin{array}{c}\text { Residual } \\
\text { activity }(\%)\end{array}$ \\
\hline 1 & Control & - & 100 \\
2 & $\mathrm{MgCl}_{2}$ & $5 \mathrm{mM}$ & 72.2 \\
3 & $\mathrm{MgCl}_{2}$ & $10 \mathrm{mM}$ & 25.9 \\
4 & $\mathrm{CaCl}_{2}$ & $5 \mathrm{mM}$ & 44.0 \\
5 & $\mathrm{CaCl}_{2}$ & $10 \mathrm{mM}$ & 111.1 \\
6 & $\mathrm{NaCl}_{7}$ & $0.5 \mathrm{M}$ & 100.0 \\
8 & $\mathrm{NaCl}_{3}$ & $1.0 \mathrm{M}$ & 50.0 \\
9 & Glycine & $0.5 \mathrm{M}$ & 61.1 \\
10 & Glycine & $1.0 \mathrm{M}$ & 50.0 \\
11 & Glycerol & $10 \%$ & 24.3 \\
12 & Mannitol & $20 \%$ & 29.1 \\
13 & Mannitol & $10 \%$ & 103.5 \\
14 & Sorbitol & $20 \%$ & 100.0 \\
15 & Sorbitol & $10 \%$ & 100.0 \\
16 & Ammonium & $20 \%$ & 54.0 \\
17 & Sulfate ammonium sulfate & $20 \%$ & 99.0 \\
\hline
\end{tabular}

\section{Discussion}

The purification procedure summarized in Table 1 shows that pectin lyase purified from culture filtrate of Fusarium oxysporum MTCC 1755 achieved 16-fold purification with $31.2 \%$ yield and $3.2 \mathrm{U} / \mathrm{mg}$ specific activity. The

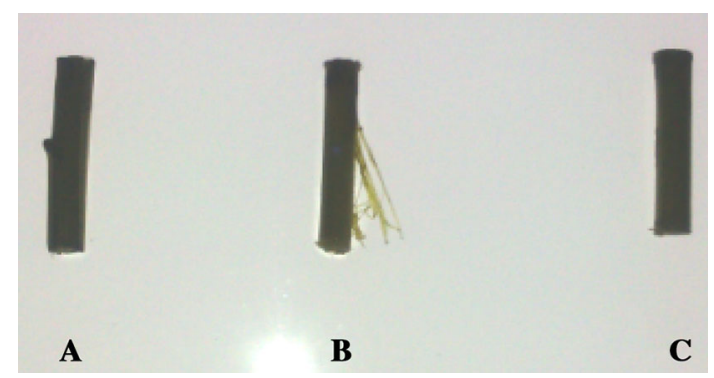

Fig. 6 Retting of Crotolaria juncea fiber by purified PNL of $F$. oxysporum MTCC 1755. a Control, b treated with enzyme without EDTA and $\mathbf{c}$ treated with enzyme with $0.01 \mathrm{M}$ EDTA

homogeneity of the enzyme confirmed by SDS-PAGE revealed a single prominent band (Fig. 2). The purification procedure involved in the present enzyme has three steps, i.e., ammonium sulfate fractionation, cation-exchange chromatography on CM cellulose and gel filtration chromatography on Sephadex G-100. Similar purification procedure has been reported in the literature for the purification of the pectin lyases from Pleurotus ostreatus and Aspergillus giganteus (Rashad et al. 2009; Pedrolli and Carmona 2014). The molecular weight determined for the purified pectin lyase was $31 \pm 01 \mathrm{kDa}$, which is similar to pectin lyase of Rhizopus oryzae (Hamdy 2005) as determined by gel filtration chromatography. An alkaline pectin lyase from A. terricola is reported to have molecular weight of $35 \mathrm{kDa}$ (Yadav et al. 2009).

The values of $K_{\mathrm{m}}$ and $k_{\mathrm{cat}}$ determined for pectin lyase from $F$. oxysporum MTCC 1755 were $1.75 \mathrm{mg} / \mathrm{mL}$ and $83.3 \mathrm{~s}^{-1}$, respectively, using citrus pectin as the substrate at $40{ }^{\circ} \mathrm{C}$. However, affinity of the enzyme for the substrate cannot be compared accurately as the substrate is a polymer with variable molecular weights $(20,000-4,00,000)$. Therefore, comparison of $K_{\mathrm{m}}$ values does not give accurate estimate of affinity of the enzyme for the substrate. The variable $K_{\mathrm{m}}$ values of $3.2,1.7,1.2$ and $0.25 \mathrm{mg} / \mathrm{ml}$ has been reported for pectin lyase of Penicillium italicum, Oidiodendron echinulatum MTCC 1356, Aspergillus flavus MTCC 10938 and Fusarium decemcellulare MTCC 2079 (Yadav et al. 2012, 2013, 2014; Alana et al. 1991). The $k_{\text {cat }}$ value of pectin lyase purified from Fusarium oxysporum MTCC 1755 was $83.3 \mathrm{~s}^{-1}$, which is in the range of 25-133 s $\mathrm{s}^{-1}$ reported for pectin lyase of Penicillium canescens using pectins with variable degrees of esterification (Sinitsyna et al. 2007).

The $\mathrm{pH}$ optimum of $F$. oxysporum pectin lyase was found to be 9.0 which is quite similar to what has been reported for PNL purified from another strain of $F$. oxysporum and $F$. decemcellulare MTCC 2079 (Yadav et al. 2014; GuevaraMA and Estevez 1996). Optimum pH of 8.0-8.5 have been reported from a number of microbial sources, viz., A. flavus, A. terricola, Bacillus clausii, 
Pythium splendens, P. oxalicum and Cystofilobasidium capitatum (Chen and Tseng 1998; Yadav and Shastri 2007; Nakagawa et al. 2005; Yadav et al. 2009, 2013; Li et al. 2012).

Temperature optimum of the purified pectin lyase was determined to be $40{ }^{\circ} \mathrm{C}$, which is in the same range $40-60{ }^{\circ} \mathrm{C}$ as reported in the literature for PNLs of Thermoascus aurantiacus, Aspergillus giganticus and Fusarium decemcellulare MTCC 2079 (Yadav et al. 2014; Pedrolli and Carmona 2014; Martins et al. 2002) but different from temperature optima of $35^{\circ} \mathrm{C}$ for PNL of Lasiodiplodia theobromae (Adejuwon and Olutiola 2007). The present enzyme was found to be quite stable in the $\mathrm{pH}$ range 5.0-7.0 when exposed for $24 \mathrm{~h}$; however, it loses its activity above $\mathrm{pH} 9.0$ as shown in Fig. 3. Pectin lyase from Aspergillus giganticus and Aspergillus niger have been reported to show a $\mathrm{pH}$ stability in the range of 3.0-7.0 (Pedrolli and Carmona 2014; Xu et al. 2015). Recent reports on purification strategies along with biochemical attributes of pectin lyase from few microbial strains have been summarized in Table 4 .

When the purified enzyme was exposed for half an hour at various temperatures $\left(10-100{ }^{\circ} \mathrm{C}\right)$ and then assayed for pectin lyase activity, it was found to retain $98 \%$ of the activity up to $50{ }^{\circ} \mathrm{C}$ but the activity started to decrease thereafter. Similar value of temperature stability has been reported in the literature for PNL from Oidiodendron echinulatum MTCC 1356 (Yadav et al. 2008) though this value was higher than PNL of Aspergillus giganticus (Pedrolli and Carmona 2014). The thermostability of the purified enzyme was enhanced when exposed to $10 \mathrm{mM}$ concentration of $\mathrm{CaCl}_{2}$ while $1 \mathrm{M} \mathrm{NaCl}$ decreases the thermal stability. It was observed that $10 \%$ ammonium sulfate retains the activity. Sugars like mannitol and $5 \mathrm{mM}$ sorbitol showed no effect on thermostability while glycerol at 10 and $20 \mathrm{mM}$ decreased the stability at $50{ }^{\circ} \mathrm{C}$.

Among metal ions and protein inhibitors, $\mathrm{Ca}^{2+}, \mathrm{K}^{+}$, $\mathrm{Na}^{+}, \mathrm{Zn}^{2+}, \mathrm{Ag}^{+}, \mathrm{Hg}^{+}, \mathrm{Co}^{2+}$ ions were found to stimulate the enzyme activity to a significant level whereas citric acid, EDTA, potassium permanganate and potassium ferrocyanide inhibited the total activity of the pectin lyase at $1 \mathrm{mM}$. $\mathrm{Cu}^{2+}$ does not affect the PNL activity. It was interesting to note that particularly $\mathrm{Ca}^{2+}$ increased the activity up to 35 -fold as compared to activity in native form, which is a distinguishing feature of pectate lyases; however, a calcium-dependent pectin lyase has also been reported in the literature (Pedrolli and Carmona 2014). The effects of metal ions and protein inhibitors on the activity of the purified PNL are reported to be quite variable from different microbial sources. The effect of $\mathrm{K}^{+}, \mathrm{Ca}^{2+}, \mathrm{Na}^{+}$ and $\mathrm{Mg}^{2+}$ on the activity of pectin lyase from $L$. theobromae (Adejuwon and Olutiola 2007) has been studied in the concentration range of $0-30 \mathrm{mM}$. The activity of pectin lyase was found to increase when subjected to $15 \mathrm{mM}$ of
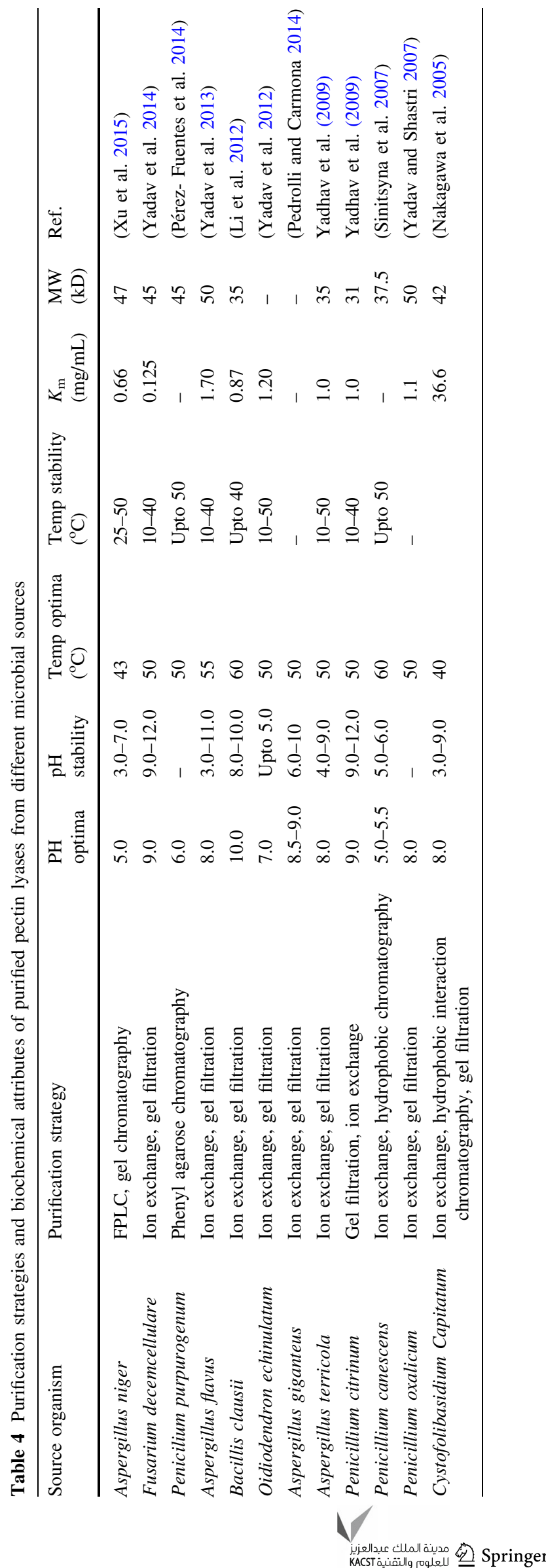
$\mathrm{Ca}^{2+}, 20 \mathrm{mM}$ of $\mathrm{K}^{+}$and $25 \mathrm{mM}$ of $\mathrm{Na}^{+}$and $\mathrm{Mg}^{2+}$ while the activity declined at $30 \mathrm{mM}$ concentration for all the ions. The activity of the enzyme was inhibited by $10 \mathrm{mM}$ EDTA and $6 \mathrm{mM} \mathrm{Hg}^{2+}$ (Adejuwon and Olutiola 2007).

Microbial pectinases are important group of enzymes with potential applications in various industries such as wine industry, paper industry, textile industry and food industry (Garg et al. 2016). Alkaline pectin lyases are promising enzyme for retting of fibers as reviewed recently (Kohli and Gupta 2015; Yadav et al. 2016). Based on alkaline nature of purified pectin lyase of $F$. oxysporum MTCC 1755, attempt was made to investigate its application in retting of available natural fiber, i.e., Crotolaria juncea. The results of retting experiments using purified pectin lyase in the absence of EDTA for Crotolaria juncea sticks shown in Fig. 6 reveal efficient retting, which could be commercially exploited after scale-up for textile industries. These results are in agreement with our previous observation that EDTA inhibits the activity of pectin lyase (Table 2) produced by F.oxysporum. Retting of Crotolaria juncea fiber in the absence of EDTA has earlier been reported for fungal pectin lyases, namely Aspergillus flavus MTCC 7589, Aspergillus terricola MTCC 7588, Penicillium citrinum MTCC 8897, Aspergillus flavus MTCC 10938, and Fusarium decemcellulare MTCC 2079 (Yadav et al. 2008, 2009a, b, 2013, 2014). In contrast, efficient retting in the presence of EDTA has also been reported in the literature (Yadav et al. 2012; DE Henrikkson et al. 1997). Since the efficiency of enzymatic retting is influenced by several factors like nature of fibers, enzyme composition, treatment duration, concentration of enzymes, use of additives like EDTA, etc. (Garg et al. 2016), there is a need for further investigation of the purified PNL of $F$. oxysporum MTCC 1755 using different fibers.

Thus, this communication reports about the purification and enzymatic characterization of an alkaline pectin lyase from a new fungal strain Fusarium oxysporum MTCC 1755. Further, its potential application in retting of Crotolaria juncea sticks in the absence of EDTA has been elucidated. The purified pectin lyase also reveals enhanced thermostability in the presence of ammonium sulfate and $\mathrm{Ca}^{2+}$ seems to be drastically influencing the enzyme activity, which is a matter of further investigation.

Acknowledgements The financial support of SERB, Government of India, New Delhi in the form of a SERB-Young Scientist Fellowship SB/FT/LS-430/2012 to Sangeeta Yadav is thankfully acknowledged. The laboratory facilities provided by Head, Biotechnology Department, DDU Gorakhpur University, Gorakhpur is thankfully acknowledged.

\section{Compliance with ethical standards}

Conflict of interest Authors have no conflict of interest.

\section{References}

Adejuwon AO, Olutiola PO (2007) Pectin lyase activity in culture medium of Lasidioplodia theobromae. J Plant Sci 2:334-340

Aguilar G, Huirton C (1990) Constitutive exo-pectinase produced by Aspergillus sp. CH-Y-1043 on different carbohydrate source. Biotechnol Lett 2:655-660

Alana A, Maria JL, Serra JL (1991) Purification and some properties of pectin lyase from Penicilliumitalicum. FEBS 280:335-340

Albersheim P (1966) Pectin lyase from fungi. Methods Enzymol 8:628-631

Bonnin E, Garnier C, Ralet MC (2014) Pectin-modifying enzymes and pectin-derived materials: applications and impacts. Appl Microbiol Biotechnol 98:519-532

Caffall KH, Mohnen D (2009) The structure, function and biosynthesis of plant cell wall pectic polysaccharides. Carbohydr Res 344:1879-1900

Chen WC, Hsieh HJ, Tseng TC (1998) Purification and characterization of a pectin lyase from Pythium splendens infected cucumber fruits. Bot Bull Acad Sin 38:181-186

DE HenrikksonG Akin, Hanlin RT, Rodriguez C, Archibald D, Rigsby LL, Eriksson KEL (1997) Identification and retting efficiencies of fungi isolated from dew retted flax in United State and Europe. Appl Environ Microbiol 63:3950-3956

Garg G, Singh A, Kaur A, Singh R, Kaur J, Mahajan R (2016) Microbial pectinases: an ecofriendly tool of nature for industries. 3. Biotech 6:47

GuevaraMA Gonzalez-Jaen MT, Estevez P (1996) Pectin lyase from Fusarium oxysporum f. sp. radicis lycopersici: purification and characterization. Prog Biotechnol 14:747-760

Hamdy HS (2005) Purification and characterization of the pectin lyase produced by Rhizopusoryzaegrown on orange peels. Ann Microbiol 55:205-211

Jun H, Kieselbach T, Jonsson L (2011) Enzyme production by filamentous fungi: analysis of the secretome of Trichoderma reesii grown on unconventional carbon sources. Microb Cell Fact 10:68

Kashyap DR, Vohra PK, Chopra S, Tewari R (2001) Applications of pectinases in the commercial sector: a review. Bioresour Technol $77: 215-227$

Kashyap DR, Soni SK, Tewari R (2003) Enhanced production of pectinase by Bacillus sp. DT7 using solid state fermentation. Bioresour Technol 88(3):251-254

Kohli P, Gupta R (2015) Alkaline pectinases: a review. Biocatal Agric Biotechnol 4:279-285

Laemmli UK (1970) Cleavage of structural proteins during the assembly of the head of bacteriophage T4. Nature 227(5259):680-685

Li Z, Bai Z, Zhang B, Li B, Jin B, Zhang M, Lin F, Zhang H (2012) Purification and characterization of alkaline pectin lyase from a newly isolated Bacillus clausii and its application in elicitation of plant disease resistance. Appl Biochem Biotechnol 167(8):2241-2256

Lowry OH, Rose Brough NJ, Farr AL, Randall RJ (1951) Protein measurement with Folin phenol reagent. J Biol Chem 193:265-275

Martin N, De Souza SR, Da Silva R, Gomes E (2004) Pectinase production by fungal strains in solid-state fermentation using agro-industrial bioproduct. Braz Archives of Biol Technol 47:813-819

Martins ES, Silva D, Da Silva R, Gomes E (2002) Solid state production of thermostable pectinases from thermophilic Thermoascus aurantiacus. Process Biochem 37:949-954

Meenakshisundaram V (2012) Optimization of pectinase enzyme production by using sour orange peel as substrate in solid state fermentation. Asian J Biochem Pharm Res 2:16-26 
NakagawaT Nagaoka T, Miyaji T, Tomizuka N (2005) A cold active pectin lyase from psychrophilic and basidiomycetous yeast Cystofilobasidium capitatum strain PPY-1. Biotechnol Appl Biochem 42:193-196

Pedrolli DB, Carmona EC (2014) Purification and characterization of a unique pectin lyase from Aspergillus giganteus able to release unsaturated monogalactouronate during pectin degradation. Enzyme Research Article ID 353915:1-7

Pérez- Fuentes C, Cristina RM, Eyzaquirre J (2014) Heterologous expression of a Penicillium purpurogenum pectin lyase in Pichia pastoris and its characterization. Fungal Biol 118(5-6):507-515

Rashad MM, Abdou HM, Shousha WGH, Ali MM, El-Sayed NN (2009) Utilization of some food processing wastes for production of pleuratusostreatus pectinases. Advan Food Sci 31:151-157

Sakai T (1992) Degradation of pectins (1992). In: Winkelmann G (ed) Microbial degradation of natural products. $\mathrm{VCH}$, Weinheim, pp 57-81

Sharma N, Rathore M, Sharma M (2013) Microbial pectinase: sources, characterization and applications. Rev Environ Sci Bio/ Technol 12(1):45-60

SinitsynaOA Fedorova EA, Semenova MV, GusakovAV Sokolova LM, Bubnova TM, Okunev ON, Chulkin AM, Vavilova EA, Vinetsky YP, Sinitsyn AP (2007) Isolation and characterization of extracellular pectin lyase from Penicillium canescens. Biochem (Moscow) 72:565-571

Tivkaa A, Bukola AT, Uduak NN, Benjamin A (2013) Production and partial characterization of pectinases from mango peels by Aspergillus tamari. J Microbiol Biotechnol Food Sci 3:59-62

Werber K, Osborn M (1969) The relative mobility or molecular weight determination by dodecyl sulfate-polyacrylamide gel electrophoresis. J Biol Chem 244:4406-4412

Whitaker JR (1990) Microbial pectolytic enzymes. In: Fogarty WM, Kelly CT (eds) Microbial Enzymes and Biotechnology, 2nd edn. Elsevier Applied Science, New York, pp 133-176

Xu SX, Qin X, Liu B, Zhang DQ, Zhang W, Wu K, Zhang YH (2015) An acidic pectin lyase from Aspergillus niger with favourable efficiency in fruit juice clarification. Lett Appl Microbiol 60(2):181-187
Yadav S, Shastri NV (2007) Purification and properties of an extracellular pectin lyase produced by the strain of Penicillium oxalicum in solid-state fermentation. Indian J Biochem Biophy 44(4):247-251

Yadav S, Yadav PK, Yadav D, Yadav KDS (2009a) Pectin lyase: a review. Process Biochem 44:1-10

Yadav S, Dubey AK, Anand G, Yadav D (2013) Purification and characterization of pectin lyase secreted by Aspergillus flavus MTCC 10938. Appl Biochem Microbiol 49(4):400-405

Yadav D, Yadav S, Dwivedi R, Anand G, Yadav PK (2016) Potential of microbial enzymes in retting of natural fibers: a review. Curr Biochem Eng 3:89-99

Yadav S, Yadav PK, Yadav D, Yadav KDS (2008) Purification and characterization of an alkaline pectin lyase from Aspergillus flavus. Process Biochemistry 43:547-552

Yadav S, Yadav PK, Yadav D, Yadav KDS (2009b) Purification and characterization of pectin lyase produced by Aspergillus terricola suitable for retting of natural fibers. Appl Biochem Biotechnol 159(1):270-283

Yadav S, Yadav PK, Yadav D, Yadav KDS (2009c) Purification and characterization of pectin lyase secreted by Penicillium citrinum. Biochemistry (Moscow) 74(7):800-806

Yadav S, Dubey AK, Anand G, Yadav D (2012) Characterization of a neutral pectin lyase produced by Oidiodendron echinulatum MTCC 1356 in solid state fermentation. J Basic Microbiol 52(6):713-720

Yadav S, Dubey AK, Anand G, Kumar R, Yadav D (2014) Purification and biochemical characterization of an alkaline pectin lyase from Fusarium decemcellulare MTCC 2079 suitable for Crotalaria juncea fibre retting. J Basic Microbiol 54(Suppl 1):S61-169

Zhang J, Henriksson H, Szabo IJ, Henriksson G, Johansson G (2005) The active component in the flax retting system of the zygomycetes Rhizopus oryzae $\mathrm{sb}$ is a family 28 polygalacturaonase. J Ind Microbiol Biotechnol 32:431-438 